\title{
GAMBARAN HISTOPATOLOGI KULIT DAN INSANG BENIH IKAN LELE (Clarias sp.) YANG TERINFEKSI Saprolegnia sp. DAN YANG TELAH DIOBATI DENGAN EKSTRAK DAUN SIRIH (Piper Betle L.)
}

\author{
Histopatologic Representation of Catfish's seeds (Clarias sp.) Skin and Gills which \\ Infected by Saprolegnia sp. and Have Been Treated by Betel Leaf Extract (Piper betle \\ L.)
}

\author{
Andriana Kusuma Wardhani ${ }^{1 *}$, Sudarno ${ }^{2}$ dan Rahayu Kusdarwati ${ }^{2}$. \\ ${ }^{1}$ Program Studi Budidaya Perairan, Fakultas Perikanan dan Kelautan, Universitas Airlangga, Surabaya \\ ${ }^{2}$ Departemen Manajemen Kesehatan Ikan dan Budidaya Perairan, Fakultas Perikanan dan Kelautan, Universitas \\ Airlangga, Surabaya \\ *andriana-k-w-fpk09.web.unair.ac.id
}

\begin{abstract}
Abstrak
Ikan lele menjadi salah satu komoditi hasil perikanan yang memiliki prospek yang sangat menjanjikan, baik dari segi permintaan maupun harga jualnya. Salah satu penyakit yang umumnya menyerang ikan lele adalah penyakit saprolegniasis yang disebabkan oleh jamur Saprolegnia sp. Tumbuhan obat tradisional yang diketahui dapat bermanfaat dalam pengendalian berbagai agen penyebab penyakit ikan, salah satunya adalah daun sirih (Piper betle L.). Tujuan dalam penelitian ini adalah untuk mengetahui gambaran histopatologi insang dan kulit benih ikan lele (Clarias sp.) yang terinfeksi oleh Saprolegnia sp. dan yang telah diobati dengan ekstrak daun sirih (Piper betle L). Penelitian ini menggunakan metode deskriptif dengan perlakuan pemberian ekstrak daun sirih dengan dosis 3,2 \%. Penelitian ini dilakukan di Laboratorium Fakultas Perikanan dan Kelautan, Universitas Airlangga Surabaya dan di Laboratorium Fakultas Kedokteran Hewan Universitas Airlangga pada bulan Agustus 2013. Hasil penelitian ini menunjukkan bahwa terjadi nekrosis pada bagian kulit benih ikan lele (Clarias sp.) yang terinfeksi Saprolegnia sp. Sedangkan pada perlakuan jaringan yang terinfeksi Saprolegnia sp. dan telah diobati dengan ekstrak daun sirih (Piper betle L) struktur jaringan kulit tetap pada kondisi normal karena Saprolegnia sp. tidak mampu menginfeksi jaringan kulit dan insang benih ikan lele (Clarias sp.).
\end{abstract}

Kata kunci: Histopatologi, Saprolegnia sp. dan Ekstrak Daun Sirih

Abstract

Catfish is one of fisheries commodity which have good prospect, in demand and also price. One of fish diseases which commonly attacked to catfish is saprolegniasis caused by Saprolegnia sp. Several traditional medicine plants which have known has advantages to control various fish diseases agent is betel leaf (Piper betle L.). The aim of this research was to know histopat represent skin and gill of catfish seeds (Clarias sp.) which infected by Saprolegnia sp and have been treated by betel leaf extract (Piper betle L.). This research using descriptive methods which treated by 3,2\% dosage of betel leaf extract. This research was done at laboratory of fisheries and marine faculty and laboratory of veterinary faculty of Airlangga University Surabaya in August 2013. The result of this research show that there was necrotic in catfish seed's skin (Clarias sp.) which infected by Saprolegnia sp. In other treatment which infected by Saprolegnia sp. and has been treated by betel leaf extract (Piper betle L.) the tissue structure still in a normal condition because Saprolegnia sp. can’t infected the skin and gill's tissue of catfish seeds (Clarias sp.).

Keywords: Histopatologic, Saprolegnia sp. and Betel Leaf Extract

\section{PENDAHULUAN}

Ikan lele menjadi salah satu komoditi hasil perikanan yang sangat digemari dan merupakan salah satu ikan yang banyak dikonsumsi masyarakat. Ikan lele digemari semua lapisan masyarakat sebagai protein hewani alternatif yang harganya murah, mudah untuk diolah, bergizi tinggi dan rasanya enak. Komoditi ini membuat ikan lele memiliki prospek yang sangat menjanjikan, baik dari segi 
permintaan maupun harga jualnya (Bachtiar, 2006).

Untuk mengatasi permasalahan akibat serangan agen patogenik pada ikan, para petani maupun pengusaha ikan banyak menggunakan berbagai bahanbahan kimia maupun antibiotika dalam pengendalian penyakit tersebut. Namun penggunaan bahan kimia dan antibiotik dengan dosis yang kurang atau tidak tepat secara kontinyu, akan menimbulkan masalah baru berupa meningkatnya resistensi mikroorganisme terhadap bahan tersebut. Selain itu, masalah lainnya adalah bahaya yang ditimbulkan terhadap lingkungan sekitarnya, ikan yang bersangkutan, dan manusia yang mengonsumsinya. Oleh sebab itu, dibutuhkan alternatif bahan obat yang lebih aman yang dapat digunakan dalam pengendalian penyakit ikan. Salah satu alternatifnya adalah dengan menggunakan tumbuhan obat tradisional yang bersifat anti parasit, anti jamur, anti bakteri, dan anti viral. Pemanfaatan tumbuhan obat tradisional memiliki beberapa keuntungan, antara lain relatif lebih aman, murah, mudah diperoleh, tidak menimbulkan resistensi, dan relatif tidak berbahaya terhadap lingkungan sekitarnya.

Beberapa tumbuhan obat tradesional yang diketahui dapat dimanfaatkan dalam pengendalian berbagai agen penyebab penyakit ikan salah satunya adalah daun sirih (Piper betle L.). Menurut Wijayakusuma dkk. (1992), sirih telah dikenal dan dimanfaatkan sejak lama di Indonesia. Semua bagian tanaman, akar, daun dan bijinya dapat digunakan untuk obat tetapi daunnya lebih banyak digunakan. Cukup banyak jenis bahan kimia yang terdapat pada sirih dan pemakaiannya sebagai obat tradisional sudah lama dikenal. Daun sirih selain mempunyai khasiat sebagai styptic (penahan darah) dan vulnerary (obat luka pada kulit) juga berdaya antioksida, antiseptik, fungisida, dan sebagai bakterisidal. Widarto (1990) juga mengatakan bahwa daun sirih mengandung minyak atsiri yang bersifat menghambat pertumbuhan mikroba.
Infeksi suatu penyakit baik yang infeksius maupun yang non-infeksius dapat didiagnosa dengan beberapa cara, diantaranya dengan diagnosa secara histopatologi yang bertujuan untuk mendapatkan berbagai informasi tentang penyakit. Histopatologi merupakan penelusuran penyakit secara mikroskopik dimana dalam pengamatan histopatologi informasi yang diperoleh dalam bentuk gambaran perubahan organ atau jaringan. Informasi yang diperoleh juga dapat digunakan sebagai data untuk mengetahui ada atau tidak infeksi penyakit serta untuk meramalkan proses kejadian penyakit dan tingkat epidemik suatu penyakit.

\section{METODOLOGI \\ Waktu dan Tempat}

Penelitian ini dilakukan di Laboratorium Basah Fakultas Perikanan dan Kelautan, Universitas Airlangga Surabaya dan di Laboratorium Histologi dan Patologi Fakultas Kedokteran Hewan Universitas Airlangga. Penelitian dilaksanakan pada bulan Agustus 2013.

\section{Materi Penelitian}

Peralatan Penelitian

Peralatan penelitian yang akan digunakan dalam penelitian ini adalah akuarium, cawan petri, labu erlenmeyer, tabung reaksi, jarum Ose, bunsen, pipet tetes, inkubator, objek gelas dan cover gelas, mikroskop, serta kamera untuk dokumentasi.

\section{Bahan Penelitian}

Bahan yang digunakan dalam penelitian ini adalah benih ikan lele (Clarias sp.), isolat jamur Saprolegnia sp., daun sirih (Piper betle L.), Saboraud Dextrose Agar (SDA), PZ (NaCl fisiologis), ethanol 95\%, akuades, organ insang dan kulit ikan lele yang telah difiksasi dalam BNF (Buffer Netral Formalin) 10\%, pewarnaan Haematoksilin-Eosin, xylol dan minyak emersi, objek gelas dan cover gelas, mikroskop. 


\section{Metode Penelitian}

Metode yang digunakan dalam penelitian ini adalah metode deskriptif, yaitu metode yang menggambarkan kejadian atau keadaan tertentu. Metode dalam bentuk deskriptif termasuk dalam data kualitatif. Taylor dan Bogdan (1984) mengatakan bahwa metode kualitatif merupakan prosedur penelitian yang menghasilkan data deskriptif berupa katakata secara tertulis.

\section{Prosedur Kerja}

Prosedur penelitian meliputi pembuatan larutan zoospora, pembuatan ekstrak daun sirih, pembuatan ekstrak daun sirih, infeksi buatan Saprolegnia sp. pada benih ikan lele, dan pengobatan dengan salep ekstrak daun sirih. Pembuatan larutan zoospora adalah dengan cara memotong potongan blok agar yang terdapat jamur dan dimasukkan kedalam erlenmeyer, inkubasi dilakukan selama 2-3 hari dalam suhu $26-28^{\circ} \mathrm{C}$. Pembilasan hifa menggunakan air steril dalam cawan petri sebanyak dua kali dan dipindahkan kedalam labu ukur yang telah diisi dengan air steril lalu inkubasi selama 24-25 jam.

Pembuatan ekstrak daun sirih menggunakan 500 gram daun sirih segar yang berukuran 7-8 cm kemudian dicuci, dikeringkan dan dihaluskan. Daun sirih direndam dalam larutan $n$-hexane selama 5 hari untuk menghilangkan klorofil yang terkandung di dalamnya. Tahap selanjutnya adalah perendaman dengan etanol 95\%. Ekstraksi dilakukan dengan merendam serbuk daun sirih dengan etanol 95\% selama 3x24 jam. Selanjutnya ekstraksi yang sudah direndam disaring menggunakan kertas saring. Hasil penyaringan diuapkan menggunakan rotary vacuum evaporator pada suhu $40^{\circ} \mathrm{C}$. Hasil ekstraksi berbentuk kental dan berwarna hijau.

Pembuatan salep ekstrak daun sirih yang dibuat sebanyak 10 gram dengan dosis 3,2\%. Pembuatan dosis salep ekstrak daun sirih sebanyak 10 gram terdiri dari 3,2 gram ekstrak dan 6,8 gram vaseline. Dosis ekstrak tersebut akan dicampur dengan vaseline dan dihomogenisasi menggunakan mortar. Infeksi buatan Saprolegnia sp. pada benih ikan lele dilakukan dengan cara perendaman spora Saprolegnia sp. kurang lebih selama tujuh hari.

Pengobatan dengan ekstrak daun sirih dilakukan dengan metode pengolesan dengan dosis 3,2\% (Widya, 2013). Proses pengolesan diawali dengan menarik jamur Saprolegnia sp. pada bagian tubuh ikan yang terkena jamur kemudian diolesi secukupnya pada bagian tubuh yang terinfeksi Saprolegnia sp. dengan ekstrak daun sirih. Ikan yang sudah diberi perlakuan ini kemudian dimasukkan kembali ke dalam akuarium yang diisi dengan air bersih sebagai tempat pengobatan dan pemeliharaan. Selama proses pengobatan ini tidak lupa ikan diberi pakan berupa pelet sebanyak 2 kali dalam sehari.

\section{Parameter Penelitian}

Parameter utama dalam penelitian ini adalah adanya perubahan histopatologi pada insang dan kulit benih ikan lele (Clarias sp.) yang terinfeksi oleh Saprolegnia sp. dan diobati dengan ekstrak daun sirih (Piper betle L.). Pengolesan ekstrak daun sirih yang berbentuk salep kepada insang dan kulit benih ikan lele ini dilakukan sebanyak dua kali sehari sampai kurang lebih tujuh hari. Sedangkan parameter penunjang dalam penelitian ini adalah pengukuran suhu, pengukuran derajat keasaman $(\mathrm{pH})$, serta pengukuran oksigen terlarut (DO).

\section{Analisis Data}

Data yang diperoleh dari kegiatan penelitian akan diolah dan dijelaskan secara deskriptif dalam bentuk tulisan, gambaran histopatologi bagian tubuh ikan lele yang masih sehat, gambaran histopatologi benih ikan lele yang terinfeksi Saprolegnia sp. serta gambaran histopatologi benih ikan lele yang telah diobati dengan ekstrak daun sirih (Piper betle L.). Kemudian dilakukan pengambilan foto sebagai dokumentasi dengan menggunakan 
mikroskop cahaya dengan perbesaran 100x.

\section{HASIL DAN PEMBAHASAN \\ Hasil Gambaran Histopatologi Kulit dan Insang Benih Ikan Lele}

Dari penelitian yang dilakukan telah didapatkan hasil preparat histopatologi yaitu ,insang dan kulit benih ikan lele yang sehat sebagai kontrol, insang dan kulit benih ikan lele yang mendapat perlakuan terinfeksi oleh Saprolegnia sp., serta insang dan kulit benih ikan lele yang terinfeksi Saprolegnia dan telah diobati menggunakan ekstrak daun sirih (Piper betle L.). Preparat tersebut kemudian diamati dan dibaca perubahan jaringan yang terjadi dan berikut adalah perbandingan antara preparat normal dengan preparat yang mendapatkan telah mendapatkan perlakuan berupa infeksi dan pengobatan.

\section{Kulit Normal (Kontrol)}

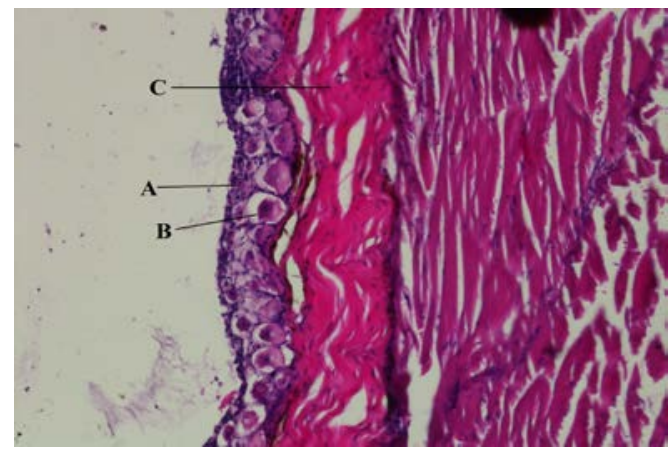

Gambar 1. Gambaran histopatologi kulit benih ikan lele kontrol, pewarnaan HE, perbesaran 200x.

Keterangan: (a) sel mukus; (b) kelenjar mukus; (c) epidermis

Pada gambar 1 dapat dilihat penampang kulit benih ikan lele yang tidak diberi perlakuan infeksi sebagai kontrol susunan jaringan histolopatoginya normal, sel mukus, epidermis, dermis dan stratum compactum pada jaringan tersebut terlihat normal dan tidak terjadi perubahan jaringan. Hal ini menunjukkan bahwa tidak ada infeksi organisme asing pada permukaan kulit benih ikan lele.

\section{Insang Normal (Kontrol)}

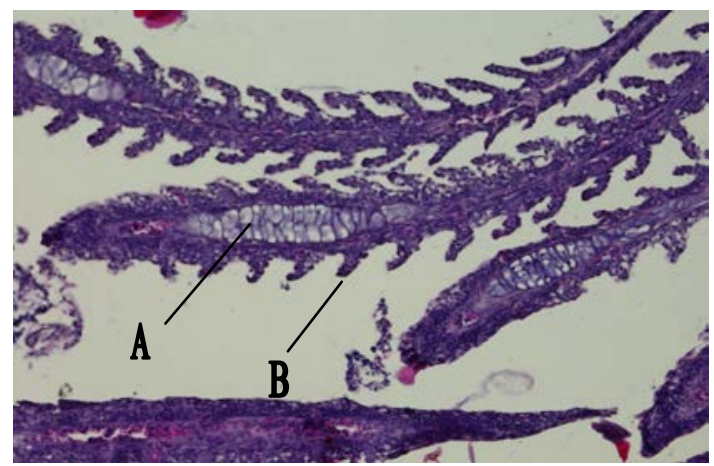

Gambar 2. Gambaran histopatologi insang benih ikan lele kontrol, pewarnaan HE, perbesaran 200x.

Keterangan : (A) Lamela primer; (B) Lamela sekunder.

Pada gambar 2 diatas menunjukkan gambar penampang insang benih ikan lele yang tidak diinfeksi sebagai kontrol, dapat terlihat bahwa insang tersebut tidak terjadi perubahan jaringan. Tidak terjadi terjadi kerusakan pada jaringan lamela primer dan lamela sekunder.

\section{Kulit Terinfeksi Saprolegnia sp.}

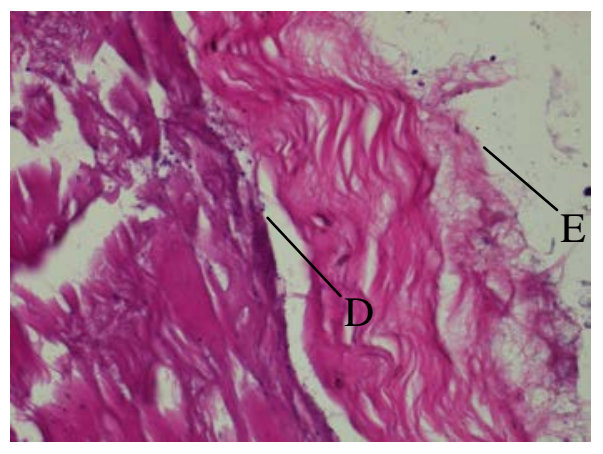

Gambar 3. Gambaran histopatologi kulit benih ikan lele yang terinfeksi Saprolegnia., pewarnaan HE, perbesaran 400x.

Keterangan : (d) epidermis; (e) basal layer

Pada gambar 3 diatas terlihat bahwa terdapat perubahan jaringan pada kulit benih ikan lele yang terinfeksi oleh Saprolegnia sp. yaitu nekrosis pada sel mukus, sel mukus ini mengalami kerusakan sel yang mengakibatkan hilangnya 
sel mukus dan kelenjar mukus pada permukaan kulit benih ikan lele. Sel yang telah mengalami nekrosis ini tidak dapat menyerap zat warna pada proses pewarnaan HE sehingga pada preparat histopatologi sel mukus dan kelenjar mukus ini tidak dapat terbaca.

\section{Insang Terinfeksi Saprolegnia sp.}

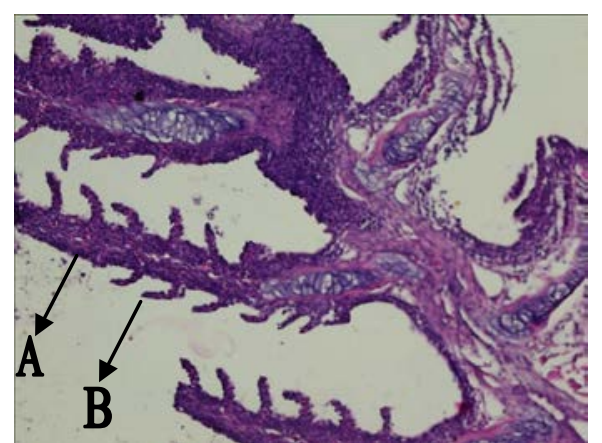

Gambar 4. Gambaran histopatologi insang benih ikan lele yang terinfeksi Saprolegnia. pewarnaan HE, perbesaran 200x.

Keterangan : (A) Lamella primer; (B) Lamela sekunder

Pada gambar 4 menunjukkan gambaran histopatologi insang benih ikan lele yang telah terinfeksi oleh jamur Saprolegnia sp., tidak terdapat perubahan patologi pada jaringan tersebut karena Saprolegnia sp. hanya melekat pada permukaan insang sehingga jaringan insang benih ikan lele tersebut tidak mengalami perubahan patologi.

\section{Kulit yang Diobati dengan Ekstrak Daun Sirih (Piper betle L.)}

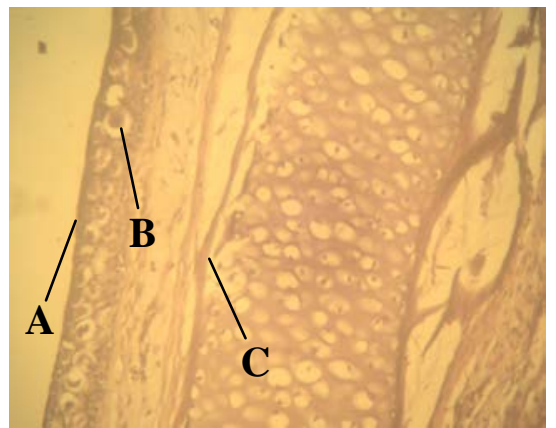

Gambar 5. Gambaran histopatologi kulit benih ikan lele setelah pengobatan.
Pewarnaan HE, perbesaran 100x. (a) sel mukus; (b) kelenjar mukus; (c) epidermis

Pada gambar 5 menunjukkan gambaran histopatologi kulit benih ikan lele yang telah diberi ekstrak daun sirih yang dioleskan pada permukaan kulit, jaringan yang ditunjukkan pada preparat diatas merupakan jaringan yang menjadi normal setelah terinfeksi oleh Saprolegnia sp. dan tidak terdapat perubahan patologi pada preparat tersebut.

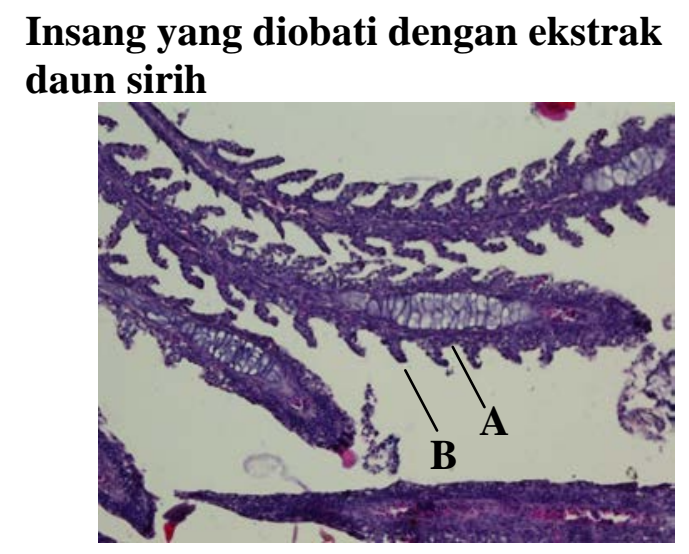

Gambar 6. Gambaran histopatologi insang benih ikan lele setelah diobati dengan ekstrak daun sirih, pewarnaan HE, perbesaran 200x.

Keterangan : (A) Lamella primer; (B) Lamela sekunder

Pada gambar 6 diatas menunjukkan gambaran histopatologi insang benih ikan lele yang telah diobati dengan ekstrak daun sirih (Piper betle L.). Preparat diatas menunjukkan tidak terdapat perubahan patologi pada jaringan insang benih ikan lele tersebut. Pengobatan yang telah dilakukan dengan cara pengolesan pada permukaan tubuh benih ikan lele juga tidak terlihat adanya perubahan patologi pada insang tersebut.

\section{Pembahasan}

Hasil pembacaan preparat histopatologi menunjukkan bahwa tidak terjadi perubahan yang berarti pada kulit dan insang benih ikan lele baik itu yang normal 
maupun yang telah terinfeksi oleh Saprolegnia sp. Pada benih ikan lele yang sehat susunan sel mukus, epidermis, dan dermis pada kulit jaringan tidak terdapat perubahannya baik itu bentuk maupun susunannya. Sedangkan pada jaringan insang susunan lamella primer dan sekundernya juga tidak terdapat kerusakan yang terjadi.

Pada benih ikan lele yang terinfeksi oleh Saprolegnia sp. terjadi kerusakan susunan jaringan dikulit berupa nekrosis. Prince dan Wilson (2006) mengemukakan bahwa nekrosis merupakan sel-sel yang mempunyai aktivitas yang sangat rendah dan akhirnya mengalami kematian sel jaringan sehingga menyebabkan hilangnya fungsi pada daerah yang mengalami nekrosis. Karakteristik dari jaringan nekrotik, yaitu memiliki warna yang lebih pucat dari warna normal, hilangnya daya rentang (jaringan menjadi rapuh dan mudah terkoyak), atau memiliki konsistensi yang buruk atau pucat (seperti bubur), dan kadang-kadang menimbulkan bau yang tidak enak serta kalsifikasi.

Sedangkan pada insang benih ikan lele yang telah terinfeksi oleh Saprolegnia sp. tidak menunjukkan tanda perubahan jaringan yang terjadi, sebab hifa jamur Saprolegnia sp. hanya menempel pada permukaan insang, sehingga pada saat dilakukan pembacaan preparat histopatologi tidak terlihat adanya perubahan patologi pada jaringan insang benih ikan lele.

Hasil pembuatan preparat kulit benih ikan lele yang telah dilakukan pengobatan berupa pemberian ekstrak daun sirih (Piper betle L.) menunjukkan bahwa tidak terjadi kerusakan pada susunan jaringan tersebut.

Senyawa aktif yang terkandung dalam daun sirih (Piper betle L.) dan bersifat antifungi yaitu fenil propane (senyawa fenolik). Adanya senyawa fenol sebagai zat anti mikroba yang terdapat dalam ekstrak daun sirih dapat merusak dinding sel fungi, sehingga menyebabkan pertumbuhan jamur menjadi lambat (Achmad dan Ido, 2009). Eugenol juga memiliki kandungan analgetik dan antifungal dengan menghambat pertumbuhan yeast (sel tunas) dengan cara mengubah struktur dan menghambat sintesis dinding sel, sehingga menyebabkan kematian sel (Oktaviani, 2012).

Hasil pembuatan preparat pada insang benih ikan lele yang diberikan pengobatan dengan ekstrak daun sirih (Piper betle L.) menunjukkan tidak ada perubahan yang berarti pada jaringan yang diamati antara insang benih ikan lele yang normal, terinfeksi Saprolegnia sp. dan yang telah dilakukan pengobatan menggunakan ekstrak daun sirih (Piper betle L.)

\section{Kualitas Air}

Parameter kualitas air yang diamati antara lain suhu, $\mathrm{pH}$ dan oksigen terlarut. Suhu air media pemeliharaan berkisar 27$28{ }^{\circ} \mathrm{C}$ yang diukur menggunakan termometer. Oksigen terlarut (DO) berkisar 4-5 mg/l diukur menggunakan DO meter. Menurunnya oksigen terlarut dalam air dapat mengurangi nafsu makan ikan yang pada akhirnya menyebabkan pertumbuhan akan terganggu (Sharfrudin dkk., 2006). Kadar oksigen di suatu perairan yang rendah dapat menyebabkan ikan menjadi stres sehingga sistem imun menjadi menurun. Pada saat itu serangan penyakit akan mudah masuk ke dalam tubuh ikan. dan $\mathrm{pH}$ berkisar 7 yang diukur menggunakan kertas lakmus. Menurut Bachtiar (2006), derajat keasaman yang ideal untuk pertumbuhan ikan lele yaitu 6,5-8. Dengan menjaga kualitas air, penyakit jamur Saprolegnia sp. dapat dicegah.

\section{KESIMPULAN DAN SARAN Kesimpulan}

Berdasarkan hasil penelitian yang telah dilakukan dapat ditarik kesimpulan gambaran histopatologi pada jaringan insang benih ikan lele yang terinfeksi oleh Saprolegnia sp. tidak terjadi perubahan histopatologi, sedangkan pada jaringan kulit benih ikan lele yang terinfeksi oleh Saprolegnia sp. terjadi perubahan histopatologi yaitu nekrosis. Gambaran 
histopatologi pada jaringan kulit dan insang yang telah diobati oleh ekstrak daun sirih (Piper betle L.) tidak terjadi perubahan histopatologi atau sama seperti gambaran histopatologi jaringan yang normal.

\section{Saran}

Agar mendapatkan hasil yang maksimal mengenai perubahan histopatologi pada benih ikan lele (Clarias sp.) yang terinfeksi oleh jamur Saprolegnia sp. dan keefektivitasan ekstrak daun sirih (Piper betle L.) untuk mengobati ikan yang terserang jamur Saprolegnia sp, perlu dilakukan penelitian lebih lanjut dengan menggunakan metode dan peralatan yang lebih kompleks.

\section{DAFTAR PUSTAKA}

Achmad dan Ido, S. 2009. Pengujian Aktivitas Ekstrak Daun Sirih (Piper betle Linn) terhadap Rhizoctonia sp. secara in vitro. Departemen Manajemen Hutan. Fakultas Kehutanan. Institut Pertanian Bogor. Bogor. Hal 1-7.

Bachtiar, Y. 2006. Panduan Lengkap Budidaya Ikan Lele Dumbo. 101 hal.

Oktaviani, D. 2012. Uji Banding Efektivitas Ekstrak Daun Sirih Merah (Piper crocatum) dengan Zinc Pyrithione $1 \%$ terhadap Pertumbuhan Pityrosporum Ovale pada Penderita Berketombe. Program Pendidikan Sarjana Kedokteran. Fakultas Kedokteran. Universitas Diponegoro. Semarang. Hal 16.

Prince, S. A., and Wilson, L. M. 2006. Patofisiologi. Edisi VI. volume I. EGC. Philadelphia.

Sharfrudin, D., Yuniarti dan Setiawati, M., 2006. Pengaruh Kepadatan Benih Ikan Lele Dumbo (Clarias sp.) terhadap Produksi pada Sistem Budidaya dengan Pengendalian Nitrogen melalui Penambahan
Tepung Terigu. Jurnal Akuakultur Indonesia 5(2) : 137-147.

Soetomo, M. H. A. 1987. Teknik Budidaya Ikan Lele Dumbo. Sinar Baru. Bandung. 109 hal..

Taylor, S. J., and Bogdan, R. 1984. Introduction to Qualitative Reseach Methods: the Search for Meanings. New York: John Wiley and Sons.

Widarto, H. 1990. Pengaruh Minyak Atsiri Daun Sirih (Piper betle L.) terhadap Pertumbuhan Bakteri Escherichia coli dan Staphylococcus aureus. Skripsi. Fateta-IPB, Bogor.

Widya, P. 2013. Pengaruh Ekstrak Daun Sirih (Piper betle L.) terhadap Tingkat Kesembuhan Benih Ikan Lele Dumbo (Clarias sp.) yang Terinfeksi Saprolegnia sp. Skripsi. Fakultas Perikanan dan Kelautan Universitas Airlangga. Surabaya.

Wijayakusuma, H. M., S. Dalimartha, dan A. S. Wirian. 1992. Tanaman Berkhasiat Obat di Indonesia jilid I. Pustaka Kartini. Jakarta. 